GLOSSARY

Poverty

M Mowafi, M Khawaja

J Epidemiol Community Health 2005;59:260-264. doi: 10.1136/jech.2004.022822

This glossary addresses the complex nature of poverty and raises some conceptual and measurement issues related to poverty in the public health literature, with a focus on poor countries.

See end of article for authors' affiliations

.....................

Correspondence to: Dr M Khawaja, Center for Research on Population and Health, American University of Beirut, Beirut 1107 2020, Lebanon; mk36@aub.edu.lb

Accepted for publication 21 June 2004
W hat is poverty? Far from simple, poverty is multidimensional in its symptoms, multivariate in its causes, dynamic in its trajectory, and quite complex in its relation to health. Concern about poverty, and its association with health, is as old as public health itself. In fact, historians trace the origins of public health back to the socioeconomic and health problems generated by rapid industrialisation during the Victorian era in Britain. It was the publication in 1842 of Chadwick's monograph on the sanitary conditions of the working classes and the subsequent public health act of 1848 that marked the "golden age" of public health. ${ }^{1}$ However, modern public health as a discipline stemmed largely out of the study of poverty with the pioneering work of Booth in London and Rowntree in York at the turn of the 20th century. ${ }^{1-3}$ The first published poverty studies did not use an empirical definition of poverty but rather estimated poverty in relative terms by evaluating overall conditions of income, food, clothing, shelter, and the like. ${ }^{2}$ In subsequent decades, central debates regarding the definition of basic needs, the role of income compared with human deprivations in the persistence of poverty, as well as the contribution of social ties and systems in reproducing and/or alleviating poverty came to the fore. The past 30 years in particular have shown significant leaps in the conceptualisation and application of poverty measures as well as in the integration of disciplines such as sociology, psychology, anthropology, and philosophy with the more traditional area of economics to resolve critical shortfalls in poverty studies. ${ }^{4}$ The result has been the emergence of multidimensional conceptions of poverty within the long established discourse of material deprivation.

Ultimately, however, conceptions of poverty are based upon societal values and norms. ${ }^{56}$ With the evolution of poverty definitions has come increased debate on issues of social and distributive justice, moral philosophy, and political responsibility. ${ }^{78}$ While explication of the full range of these topics is beyond the scope of this glossary, it is none the less important to note their role in the construction of the current poverty discourse. This glossary addresses the complex nature of poverty and raises a number of conceptual and measurement issues related to poverty in the public health literature, with a focus on poor countries.

\section{ECONOMIC POVERTY}

Economic poverty refers to a deficiency in the amount of financial resources a household has to meet its basic needs, which can be defined in either absolute or relative terms.

Absolute poverty refers to the set of resources a person must acquire to maintain a minimum standard of living for survival. It is therefore "a matter of acute deprivation, hunger, premature death and suffering." "9 From a human rights perspective, it is the responsibility of nations to ensure that its citizens have access to a level of goods that meet their basic right to health and wellbeing. ${ }^{10}$ To affirm this commitment, the international community has signed on to the goal of halving severe poverty by the year 2015 as the first of eight millennium development goals. ${ }^{11}$ What remains unresolved, however, is how "severe" or "absolute" poverty should be defined. Once decided upon, this definition can be useful for setting a target at which governments and organisations can measure, improve, and compare poverty levels at the international level.

Relative poverty is concerned with how worse off an individual or household is with respect to others in the same society. It does not necessarily reflect vulnerability to mortality or acute suffering, but rather the level of inequality in a given context. In such a circumstance, the inability to access goods or services that are considered norm could render a person poor. As far back as 1776, Adam Smith recognised the relativity of needs by defining "necessaries" as "not only the commodities which are indispensably necessary for the support of life, but whatever the custom of the country renders it indecent for credible people, even of the lowest order, to be without." 12 More recently, Townsend defined relative poverty to be the level of deprivation at which individuals are unable to "play the roles, participate in the relationships, and follow the customary behavior which is expected of them by virtue of their membership in society." ${ }^{\prime 13}$ Wilkinson argues that one should no longer speak of an absolute, but rather, relative deprivation of resources. ${ }^{14}$

Absolute poverty lines, then, are threshold below which households cannot maintain a minimum standard of living. With the exception of the USA, they are most often used in developing world contexts. In the developed world, relative income poverty lines are more often used to calculate poverty levels. In this case, the poverty threshold is commonly set at $50 \%$ of the country's median household income. Another method is to compare the difference of expenditures between 
the top fifth and lowest fifth of a population. As inequality tends to influence people's perceptions of poverty, such assessments may serve to highlight potential causes of social and political tensions. Ultimately, however, the level at which any poverty line is set may be considered arbitrary and debatable..$^{16}$ The real value of any poverty line lies in maintaining a measure for comparisons within and among groups over time.

The measurement of economic poverty entails defining a threshold (that is, line) that distinguishes the poor from the non-poor and examining the income or consumption levels of people in reference to that threshold. ${ }^{16}$ To establish a poverty line, four basic issues need to be addressed: type of data to be used (income compared with expenditure), construction of a basic needs basket, unit of analysis (individual versus family versus household), as well as the determination of a reference. To be useful, poverty lines should be internally consistent, have broad public acceptance, and be easy to implement. ${ }^{17}$

The poverty line can be based on either income or expenditure data. While income data are commonly used to measure standard of living, they suffer from many measurement problems (for example, underreporting), especially in developing countries. Expenditure data, on the other hand, contain monetary values for goods consumed and so may be used to price a basic needs basket. Although expenditure data are often assumed to better estimate need than income data, they may simply reflect personal choices of resource allocation or prudence during low income periods. Convention is to use expenditure data to calculate needs in constructing the poverty line and income data to examine which households meet a minimum standard of living, or their basic needs.

Several approaches have been taken to establish a basic needs basket. Firstly, it is possible to identify the minimum energy intake necessary for subsistence (for example, 2200 calories/day) and establish the line as the income below which a person would be unable to meet this need. A multiplier may be added to account for non-food necessities, or alternatively, the equivalent amount may be added to the line by identifying their share of total expenditure at the minimum energy intake. This method was established by Orshansky in the USA in the early 1960s and was widely adopted by many other countries as well. ${ }^{18}$ Recent recommendations to update the US poverty line have included food, clothing, shelter, and a multiplier to account for nondiscretionary expenses that may differ per individual. ${ }^{17}$ Yet others, taking a health and human rights perspective, ${ }^{19-21}$ advocate that health services should be included as a basic need in calculating the poverty line.

In measuring poverty, the unit of analysis may be defined as the household, family, or individual. Typically, poverty is measured at the household or family level because this entity constitutes a natural income pooling unit. Poverty lines based on the individual, although ideal in their level of representation, cannot be easily constructed because of the lack of data on individual income/expenditure. The family as a unit of analysis can be very useful for policy purposes as public assistance programmes are often based on family types. Also, while households may represent more than one consumption unit, the family most often represents only one consumption unit. For practical purposes, however, the household is generally considered the standard unit of analysis in poverty research because most international surveys collect information at the household level. ${ }^{22}$

The reference household is usually the most demographically represented-that is, the household composition of largest proportion in the population. The spending patterns of this reference are then used as the basis for calculating poverty lines for other household types in the population.
Equivalence scales are used to adjust the poverty line for various household sizes and compositions. They are based on the idea that the household is not necessarily equal to the sum of its parts. In other words, individuals within the household may have varying needs and consumption demands. For example, while an adult may require a certain energy diet for subsistence, a child may need much less. In this case, one may not equate the cost of these two individuals in the household. In the same vein, while living alone may cost a set amount, addition of another adult leads to a situation of pooled consumption in which both individuals may share in the use of certain public goods (for example, shelter, food, heating). In this case, adding a person to the household also does not add up to the sum of the two parts. This phenomenon is referred to as economies of scale. Although the OECD equivalence scale is commonly used in the literature, it is important to note that a variety of equivalent scales are available and each may systematically affect the absolute or relative levels of poverty apparent in a given population. ${ }^{23}$

Although current poverty lines are invaluable in assessing poverty and inequality between households, they are ineffective in capturing disparities within households. As poverty statistics are generally collected through household living standard surveys, the relative needs and consumption patterns of individual members are not adequately taken into account. This can be a significant limitation because if it is possible for non-poor households to contain poor individuals. For example, in the case of women, a significant literature has emerged discussing gender inequities in poverty and health outcomes because of discrimination in intra-household distribution of resources. ${ }^{24} 25$

A potentially more efficient method of determining a poverty line, however, is through what is called the "minimum income question," or MIQ. This method simply asks people how much they need to "make ends meet" using a direct survey question. The monetary values derived from this question can then be compared with actual household income (resources) after appropriate adjustments for household size and composition, to derive a subjective poverty line. ${ }^{26}$ Recent studies have found this subjective poverty line similar to those that are calculated using traditional, "objective" methods. ${ }^{27}$ If proved to be a robust approach to determine minimum living standards, the MIQ could significantly reduce the time, effort and resources needed to establish poverty lines in the future. It would also allow for more flexible and frequent inter-country and intra-country poverty analyses.

Vulnerability refers to the risk a person or group may have of crossing the poverty line. ${ }^{28-31}$ It describes the probability of becoming poor and is a function of external shocks and stresses. Some researchers note the dual risks experienced by such groups: that of external threats to livelihood and security (for example, climate, market collapse, etc) and the lack of internal preparedness for times of crises. ${ }^{32}$

The transient poor refers to those groups whose resources are only slightly above the poverty line and who have little insurance or assets to withstand external shocks. They may cross over the poverty line frequently ("the churning poor") or only occasionally. ${ }^{28}$

The chronic poor are those whose resources are severely below established needs and so they suffer from persistent deprivation. To make reference to the levels at which a person, household, or group falls below the poverty line, researchers often refer to the depth of poverty. The depth of poverty, as well as its incidence, can be measured using the poverty gap measure. The poverty gap is the mean shortfall from the poverty line (counting the non-poor as having zero shortfall), expressed as a percentage of the poverty line. ${ }^{33}$ 
Panel data are often required to distinguish the transient poor from the chronic poor. Common practice is to collect income/consumption data at the household level and follow the same households over time. Groups are then identified as chronic compared with transient poor based on the duration and/or frequency of days spent living below the poverty line over a time period.

\section{HUMAN POVERTY AND CAPABILITIES}

Human poverty is defined by "impoverishment in multiple dimensions-deprivations in a long and healthy life, in knowledge, in a decent standard of living, in participation." ${ }^{\prime 34}$ Human poverty takes a people centred approach by directing resources and attention to areas of individual capacity building such as health and education.

The human poverty index, or HPI, includes measures of life expectancy, illiteracy, access to healthcare and other public services in addition to the percentage of under 5 mortality. ${ }^{35}$ It allows for intra-country and inter-country comparisons of these indicators over time and is less subject to the wide market fluctuations that attenuate comparability of income based measures over time.

However, there are weighting problems associated with any composite index, and the HPI is no exception. Also, presenting human poverty by an overall index number can cloud the effects of inequalities within social groups (for example, gender, ethnicity, socioeconomic status). One possible remedy is to provide disaggregated estimates of the HPI, though this practice has yet to become widely adopted because of scarcity of resources.

Despite measurement shortfalls of the HPI, one of its greatest successes has been that of enlisting the support of economists in the conceptual shift toward understanding poverty as a deprivation of human capabilities. ${ }^{36}$

Capabilities deprivation, a concept principally attributed to Sen, identifies poverty in terms of "the lives people can actually lead and the freedoms they do actually have." ${ }^{137}$ As such, the "capabilities approach" extends the concept of human poverty by drawing distinct connections between development, freedom, and deprivation of human capabilities (rather than income deprivation).

Capabilities refer to the ability of a person to convert commodities into valued functionings in the context of one's life. A functioning, according to Sen, is "an achievement of a person; what he manages to do or to be." ${ }^{138}$ For example, food is a commodity that enables a person to satisfy hunger and to provide eating pleasure. And yet for a person to convert this commodity into daily "functioning", she must have the capability (that is, good health) to do so. ${ }^{38}$ As such, commodities have no intrinsic value in the absence of a person's ability to convert goods into achievements.

Going further, capabilities may be defined as the substantive freedoms an individual exercises to live a lifestyle she deems valuable. Choices are made through evaluative and reflective processes that lead to valuation rankings of the individual's priorities. The result of exercising one's choices not only affords a person freedom, but is itself only achievable through the utilisation of one's freedoms. Freedom, in this case, is considered both the ends and the means of development. ${ }^{37}$ Sen identified five instrumental freedoms for the process of development to mature: political freedom, economic facilities, social opportunities, transparency guarantees, and protective security. ${ }^{37}$

The most challenging aspect of the capabilities approach is its operationalisation. While Sen insists on leaving the "capabilities space" undefined, Martha Nussbaum criticises Sen for not "taking a stand" on what the central capabilities should be. ${ }^{39}$ If the capabilities approach is to be relevant and useful for interpersonal comparisons, she asserts, then it needs to move beyond theory toward an objective normative framework. To do this, she establishes a list of 10 capabilities considered to be the universal minimum a government must guarantee its citizens to have fulfilled its role in the development process. It includes the right to (1) life (preventing premature death); (2) bodily health (to be adequately nourished and have shelter); (3) bodily integrity (control over bodily boundaries, including protection from assault); (4) senses, imagination, and thought (to use the senses and reason, cultivated by adequate education and protected by political freedoms); (5) emotions (free to love, grieve, etc); (6) practical reason (freedom to form a personal conception of the good and to plan one's own life); (7) affiliation (freedom to engage in various social interactions); (8) interaction with other species (to interact freely with nature); (9) play (to laugh, play, and enjoy recreational activities); and (10) control over one's environment (guarantees of political participation, ownership of property, and equal employment opportunity). ${ }^{39}$ It is arguable however if and how governments could guarantee its citizens "senses", or "imagination".

\section{MULITDIMENSIONAL POVERTY}

A growing number of studies are exploring how the poor themselves conceptualise poverty. ${ }^{40-45}$ While the results of these studies can vary depending on regional concerns and interests, certain themes seem to resonate widely and have highlighted the multidimensionality of poverty.

Multidimensional poverty conceives of deprivation not only as lack of material goods, but also as deficiency in other important areas such as social capital, human capital, power, and voice. The World Bank's "voices of the poor" study, the largest participatory poverty assessment of its kind, found that rather than income, the poor are more likely to describe their reality in terms of physical, human, social, and environmental assets. ${ }^{40}$

Assets refer to resources the poor can use to manage or reduce their risk of vulnerability to external shocks. Assets may be tangible or intangible (for example, land, friends, education) and can mediate a broad array of potential hardships ranging from drought to sudden family illness.

Social exclusion focuses on the processes of marginalisation. ${ }^{46}$ Specifically, it refers to "the societal and institutional processes that exclude certain groups from full participation in the social, economic, cultural and political life of societies. ${ }^{147}$ While it is true that a person can be economically deprived without being socially excluded, the two experiences are strongly correlated. Social exclusion may lead to economic poverty directly by means of lacking social networks that provide opportunities or indirectly via disparities in the power structures of society. Interesting research on the relations between social capital, income inequality, and health outcomes has also emerged in recent years, ${ }^{48-50}$ providing even more insight into the negative consequences of social inequalities from a social justice perspective.

The ability of a group to express its concerns and determine its future is related to its level of power in society. As Narayan points out, "All societies are built from social groups rather than individuals, and these groups determine attitudes, beliefs, identities and values, as well as access to resources and opportunities-and ultimately access to power. Since most groups are not homogeneous, but are divided by class, caste, religion and ethnicity, groups differ in their access to resources and power." ${ }^{\prime 47}$

Max Weber defines power as the probability that someone, in a social relationship, will be able to achieve his or her will (that is, what is desired), despite resistance and regardless of the bases upon which the probability rests. ${ }^{51}$ On a related note, Narayan defines empowerment as "the expansion of 
assets and capabilities of poor people to participate in negotiate with, influence, control, and hold accountable institutions that affect their lives." ${ }^{2}$

It is clear that power, or access to positions and institutions that allow individuals to influence change for the interests of their groups, is a requisite for the acquisition of voice in society. Social capital, social support, and social networks can play an important part in the attainment of such positions, and so these concepts are inextricably related. ${ }^{53}$

\section{POVERTY AND HEALTH}

While it is true that poverty lends itself toward ill health, it is also true that ill health can put people at risk of becoming poor. This double edged fate has led many researchers to focus their attention on the important link between poverty and health. ${ }^{54}{ }^{55}$ The 2000/2001 World Development Report ${ }^{56}$ named health as a key dimension of poverty and discussed issues that must be addressed to mitigate this factor. A growing body of literature points to significant disparities in mortality and morbidity outcomes between populations of varying socioeconomic status. ${ }^{56-62}$ Social and economic determinants of health, therefore, are playing a greater part in the discourse of poverty. As Roberts puts it, "the determinants of [health] inequalities, in both developed and less developed countries, are social and economic, and so remedial action must also be social and economic." ${ }^{\prime \prime 3}$ In this quest, greater efforts are being made to distinguish health inequalities from health inequities ${ }^{64-67}$ and social inequalities from social inequities, ${ }^{68}$ and to bring to the fore the injustices that play a part in perpetuating the situation of poverty and ill health for the world's most disadvantaged populations. Indeed, advocates for the poor are increasingly approaching poverty alleviation from a health and human rights perspective. Highlighting issues of inequity and social injustice, ${ }^{69}$ there is a need to shift the policy agenda toward addressing the institutional biases that contribute to the persistence of poverty while calling for more accountability and transparency in the search for new solutions.

\section{Authors' affiliations}

M Mowafi, M Khawaja, Center for Research on Population and Health, American University of Beirut, Beirut, Lebanon

\section{REFERENCES}

1 Nijhuis HGJ, Van Der Maesen UG. The philosophical foundations of public health: an invitation to debate. J Epidemiol Community Health 1994:48:1-3.

2 Booth C. Life and labour of the people in London. London: Macmillan, 1902-1903.

3 Rowntree BS. Poverty: a study of town life. London: Macmillan, 1901.

4 Kanbur R. Conceptual challenges in poverty and inequality: one development economist's perspective. New York: Cornell University, 2002.

5 Sindzingre A. Values, norms and poverty: a consultation on WDR 2000/ 2001 poverty and development. Washington, DC: World Bank Group, 1999.

6 Blackwood DL, Lynch RG. The measurement of inequality and poverty: a policy maker's guide to the literature. World Development 1994;22:567-78.

7 Rawls J. A theory of justice. Cambridge: Harvard University Press, 1971.

8 Sen A. "Equality of what?". In: Liberty, equality and law. Cambridge: Cambridge University Press, 1980.

9 Schwartzman S. The statistical measurement of poverty. Rio de Janeiro, Brazil: Expert Group of Poverty Statistics, 2002

10 United Nations. Universal Declaration of Human Rights. http://www.un.org/ Overview/rights. html.

11 World Bank Group. Millennium development goals. http:// wuw.developmentgoals.org.

12 Smith A. Wealth of nations. New York: Random House, 1993.

13 Townsend P. The international analysis of poverty. Hemel Hempstead, England: Harvester-Wheatsheaf, 1992.

14 Wilkinson RG. Unhealthy societies: the afflictions of inequality. London: Routledge, 1996.

15 Lanjouw JO. Demystifying poverty lines. New York: Poverty Elimination Programme, UNDP, 1998.

16 Steele A. Poverty of definition. Rapid responses to 'eradicating child poverty. BMJ 1999;319:203-4.

17 Citro C, Michael R. Measuring poverty: a new approach. Washington DC: National Academy Press, 1995.
18 Fisher G. The development and history of the poverty thresholds. Social Security Bulletin 1992;55:3-14

19 Mann J, Gruskin S. Women's health and human rights: genesis of the health and human rights movement. Health and Human Rights 1995; 1:309.

20 Tarantola D. Building on the synergy between health and human rights: a global perpective. Boston: Francois-Xavier Bagnoud Center for Health and Human Rights, 2000

21 Mann J. Human rights and the new public health. Health and Human Rights 1995; 1:229.

22 Deaton A. The analysis of household surveys: a microeconometric approach to development policy. Baltimore: Johns Hopkins University Press, 1997.

23 Buhmann B, Rainwater L, Schmaus G, et al. Equivalence scales, well-being, inequality, and poverty: sensitivity estimates across ten countries using the Luxembourg income study (LIS) database. Review of Income and Wealth 1988:34:115-42.

24 Quisumbing AR, Haddad L, Pena C. Are women overrepresented among the poor? An analysis of poverty in 10 developing countries. Journal of Development Economics 2001;6:225-69.

25 Dasgupta P, Ray D. Adapting to undernourishment: the clinical evidence and its implications. Helsinki: WIDER working paper, 1987.

26 Khawaja M. Migration and the reproduction of poverty: the refugee camps in Jordan. International Migration 2003;41:27-56.

27 Pradhan M, Ravallion M. Measuring poverty using qualitative perceptions of consumption adequacy. Review of Economics and Statistics 2000;82:462-71.

28 Hulme D. Chronic poverty and development policy: an introduction. World Development 2003;31:399-402

29 Elbers C, Gunning JW. Estimating vulnerability. International conference on staying poor: chronic poverty and development policy, University of Manchester, 7-9 Apr, 2003.

30 McGregor JA. A poverty of agency: resource management amongst poor people in Bangladesh. Bath: Centre for Development Studies, University of Bath, 2000.

31 Mckay A, Lawson D. Assessing the extent and nature of chronic poverty in low income countries: issues and evidence. World Development 2003;31:425-39

32 Hulme D, Moore K, Shepherd A. Chronic poverty: meanings and analytical frameworks. Manchester: Chronic Poverty Research Centre, 2001.

33 Foster J, Greer J, Thorbecke E. A class of decomposable poverty measures. Econometrica 1984;59:687-709.

34 UNDP. United Nations Development Programme (UNDP) Human development report 2000: Human rights and human development. New York: Oxford University Press, 2000

35 Moez D. Analytical tools for human development. 3rd ed. New York: Human Development Report Office, UNDP, 1997.

36 Deaton A. Counting the world's poor: problems and possible solutions. New Jersey: Research Program in Development Studies, Princeton University, 2000.

37 Sen A. Development as freedom. New York: Random House, 1999.

38 Sen A. Commodities and capabilities. New York: Oxford University Press, 1985.

39 Nussbaum M. Women and human development. Cambridge: Cambridge University Press, 2000

40 Narayan D, Patel R, Sxhafft K, et al. Voices of the poor: Can anyone hear us?. New York: Oxford University Press, 2000.

41 Moore M, Choudhary M, Singh N. How can we know what they want? Understanding local perceptions of poverty and ill-being in Asia. Brighton: Institute for Development Studies, 1998.

42 Brock K. "It's not only wealth that matters - it's peace of mind too": a review of participatory work on poverty an ill-being. Brighton: Institute for Development Studies, 1999.

43 Bonn M, Earle D, Lea S, et al. South African children's' views of wealth, poverty, and inequality and unemployment. Journal of Economic Psychology 1999;20:593-612.

44 Watson D. In search of the poor. Journal of Economic Psychology 2000;21:495-515.

45 Bradshaw J, Gordon D, Levitas R, et al. Perceptions of poverty and social exclusion. Bristol: Townsend Centre for International Poverty Research, 1998.

46 Burchardt T, Le Grand J, Piachaud D, Introduction, Degrees of Exclusion. In: Hills J, Le Grand J, Piachaud D, eds. Understanding social exclusion. Oxford: Oxford University Press, 2002.

47 Narayan D. Bonds and bridges: social capital and poverty. Washington DC: World Bank, 1999

48 Hawe P, Shiell A. Social capital and health promotion: a review. Soc Sci Med 2000:51:871-85.

49 Berkman L, Glass T, Brissette I, et al. From social integration to health: Durkheim in the new millennium. Soc Sci Med 2000;51:843-57.

50 Gold R, Kennedy B, Connell F, et al. Teen births, income inequality, and social capital: developing an understanding of the causal pathway. Health and Place 2002;8:77-83.

51 Weber M. The theory of social and economic organization. New York: Oxford University Press, 1947

52 Narayan D, Chambers R, Shah MK, et al. Voices of the poor: crying out for change. New York: Oxford University Press, 2000.

53 Berkman LF, Glass T. Social integration, social network, social support, and health. In: Berkman LF, Kawachi I, eds. Social epidemiology. Oxford: Oxford University Press, 2000

54 Wagstaff A. Poverty and health. Geneva: WHO, 2001

55 Sclar ED, Northridge ME. Slums, slum dwellers, and health. Am J Public Health 2003;93:1381.

56 World Bank. World development report 2000/2001: attacking poverty. Oxford: Oxford University Press, 2000. 
57 Lochner K, Pamuk E, Makuc D, et al. State-level income inequality and individual mortality risk: a prospective, multilevel study. Am J Public Health $2001 ; 91: 385-91$

58 Messias E. Income inequality, illiteracy rate, and life expectancy in Brazil. Am J Public Health 2003:93:1294-6.

59 Rodgers GB. Income and inequality as determinants of mortality: an international cross-section analysis. Int J Epidemiol 2002;31:533-8.

60 Muller A. Education, income inequality, and mortality: a multiple regression analysis. BMJ 2002;324:23-5.

61 Kobetz E, Daniel M, Earp JA. Neighborhood poverty and self-reported health among low-income, rural women, 50 years and older. Health and Place 2003;9:263-71.

62 Lachaud, JP. Modelling determinants of child mortality and poverty in the Comoros. Health and Place 2004; 10:13-42.
63 Roberts I Poverty and child health. BMJ 1996:313.371.

64 Leon D, Walt G, Gilson L. International perspectives on health inequalities and policy. BMJ 2001;322:591-4.

65 Braveman P, Gruskin S. Defining equity in health. J Epidemiol Community Health 2003:57:254-8.

66 Kawachi I, Subramanian SV, Almeida-Filho N. A glossary of health inequalities. J Epidemiol Community Health 2002;56: 647-52

67 Wagstaff A. Poverty and health sector inequalities. Bull World Health Organ 2002:80:97-105.

68 Krieger N. A glossary for social epidemiology. J Epidemiol Community Health 2001;55:693-700.

69 Braveman P, Gruskin S. Poverty, equity, human rights and health. Bull World Health Organ 2003;81:539-45.

\section{APHORISM OF THE MONTH}

\section{"Less is usually more."}

ublic health professionals must learn to become minimalists. Less is usually more. What is needed in public health is the least intervention that makes the biggest difference.

The search for turning points, or turnkeys, should inform our efforts to mobilise resources for health.

JRA, Lowell Levin 